\title{
The endoplasmic reticulum stress response is associated with insulin resistance-mediated drug resistance in HepG2 cells
}

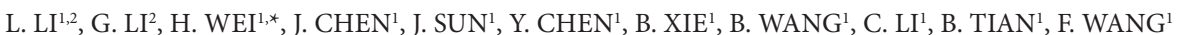

${ }^{1}$ Key Laboratory of Preclinical Study for New Drugs of Gansu Province, School of Basic Medical Sciences, Lanzhou University, 199 Donggang West Road, Lanzhou, 730000 Gansu Province, China; ${ }^{2}$ Department of Clinical Laboratory, the Second Hosiptal of Lanzhou University, Cuiyingmen No. 82, Linxia Road, Lanzhou, 730000 Gansu Province, China

*Correspondence: weihulai@lzu.edu.cn

Received January 23, 2014 / Accepted July 21, 2014

Insulin resistance has a close relationship with tumorigenesis, tumor progression, and cancer prognosis. Importantly, the liver is the main target tissue of insulin, and the resistance to chemotherapeutic agents has been reported in hepatocarcinoma. However, little is known about the relationship between drug resistance and insulin resistance in hepatocarcinoma. Therefore, we treated HepG2 cells (a human hepatoma cell line) with high concentrations of insulin to establish a cell-based model of insulin resistance (HepG2/IR cells) to define the relationship between insulin resistance and the resistance to chemotherapy. We identified that HepG2/IR cells exhibited stable insulin resistance, with decreased glucose consumption, reduced glycogen synthesis, and decreased expression of the insulin receptor gene. HepG2/IR cells also exhibited endoplasmic reticulum (ER) dilatation and degranulation. Molecular markers of endoplasmic reticulum stress, including glucose-regulated protein78 (GRP78) and phosphorylated protein kinase R-like ER kinase (p-PERK), increased significantly, which was accompanied by increased reactive oxygen metabolism and decreased mitochondrial membrane potential. In addition, HepG2/IR cells were resistant to the chemotherapy agent Adriamycin, which was accompanied by the upregulation of multidrug resistance gene 1/ P-glycoprotein (P-gp; an endoplasmic reticulum chaperone that plays a role in ER stress), and enhanced drug efflux. These data suggest that the endoplasmic reticulum (ER) stress response was active in HepG2/IR cells, and that insulin resistance was related to drug resistance in HepG2 cells. Interestingly, the ER stress and chemotherapy resistance observed in HepG2/IR cells could be reversed by treatment with the insulin sensitizer pioglitazone. Therefore, our study suggests that there is a close relationship between the resistance to chemotherapy and insulin resistance in HepG2 cells, and that the ER stress response play a role in insulin resistance-mediated drug resistance in hepatocarcinoma cells.

Key words: insulin resistance, drug resistance, P-gp, endoplasmic reticulum stress, HepG2 cells

Insulin is a signaling molecule that functions by binding to its cognate receptor to induce signal transduction. This leads to a variety of physiological effects, such as increased glucose utilization and glycogen synthesis, reduced gluconeogenesis and fat catabolism, and enhanced protein synthesis [1]. Defects in the insulin-signaling pathway, including reduced expression of the insulin receptor or affinity for insulin, and genetic mutations can cause insulin resistance (IR). IR is associated with impaired insulin sensitivity and dysglycemia, and can lead to type-II diabetes [1-3]. It has also been linked to carcinogenesis, cancer progression, and the multidrug resistance (MDR) of tumors, and is a risk factor for the recurrence of hepatocarcinoma after hepatectomy [4-13]. However, the mechanism of insulin resistance and its relationship with MDR in hepatocellular carcinoma remain unclear.

Previous studies suggested that insulin resistance and endoplasmic reticulum (ER) stress are related because ER stress occurs during conditions of insulin resistance such as hyperinsulinemia and dysglycemia. ER stress may also facilitate the development of insulin resistance by suppressing insulin action and decreasing the expression of the glucose transporters (GLUTs) [14]. Upon insulin resistance-activated ER stress, the binding of glucose-regulated protein-78 (GRP78) to unfolded proteins causes its dissociation from complexes with protein 
kinase R-like ER kinase (PERK), which leads to the activation of PERK by autophosphorylation. This induces the expression of genes that ameliorate ER stress by reducing the synthesis of new proteins that would require folding [15], and upregulates the expression of molecular chaperones involved in the unfolded protein response (UPR) such as glucose-regulated protein-78 (GRP78). GRP78 is the major molecular marker of ER stress, particularly protein folding and trafficking, which protects cells from ER dysfunction and maintains cellular homeostasis [16]. Similarly, the ER stress response activates the expression of $\operatorname{grp} 78$ in tumor cells, protecting cells from ER stress-induced apoptosis [17]. This reduces the sensitivity of cells to chemotherapy drugs, promoting cellular proliferation and reducing anti-cancer therapy-induced death in tumor cells [18].

$\mathrm{P}$-glycoprotein (P-gp) is also known as multidrug resistance protein 1 (MDR1), and is encoded by the ABCB1 ( $m d r 1$ ) gene family. It is an adenosine triphosphate-binding cassette transporter that functions as an energy-dependent efflux transporter to prevent the intracellular accumulation of cytotoxic drugs. It is also associated with multi-drug resistance in many types of tumor, including hepatocarcinoma [19-21]. The expression of $m d r 1$ in cells can be modified by several factors including stress signals and the metabolic and nutritional state [22-23]. P-gp can also play a role in the UPR, either directly by transporting misfolded proteins or indirectly by interacting with chaperones, conferring resistance to UPR-stimulated caspase-dependent apoptosis [23-24]. This suggests that MDR in tumors maybe related to the glucose abnormalities, ER stress, and the upregulation of $m d r 1$.

Until now, little was known about the upregulation of $m d r 1$ during ER stress and insulin resistance, and how it was related to MDR in hepatocarcinoma cells. Our data demonstrate that ER stress leads to increased expression of GRP78, p-PERK, and P-gp during insulin resistance in HepG2/IR cells. In addition, we report that the resistance of HepG2/IR cells to Adriamycin is accompanied by the upregulation of GRP78, p-PERK, and P-gp, which could be reversed by treatment with the insulin sensitizer pioglitazone hydrochloride. These data confirm that the resistance of HepG2/IR cells to Adriamycin is regulated by ER stress during insulin resistance.

\section{Material and methods}

All primers used to measure the InsR, mdr1, and $\beta$-actin were synthesized by Takara Corporation (Japan). SYBR Premix Ex Taq and Prime Script RT reagents were also purchased from Takara. The following antibodies were used: mouse polyclonal anti- $\beta$-actin (Biovision, USA), rabbit polyclonal anti-GRP78 (Spring, USA), rabbit polyclonal anti-p-PERK (Santa Cruz, USA), rabbit polyclonal anti-PERK (Cell Signaling Technology, USA), rabbit polyclonal antiP-gp (Biovision), and anti-INSR (Biosource, USA). Insulin was purchased from Sigma-Aldrich (USA), and diluted to the appropriate concentrations using $2 \%$ glacial acetic acid.
Pioglitazone Hydrochloride (Santa Cruz, USA) and Adriamycin (Sigma-Aldrich) were diluted in dimethyl sulfoxide (DMSO). The GOD-POD kit was purchased from Randox Laboratories (UK).

Establishing and reversing insulin resistance in HepG2 cells. HepG2 human hepatocarcinoma cells were obtained from the American Type Tissue Culture Collection (ATCC), and were maintained in Dulbecco's modified Eagle's medium (DMEM) supplemented with $10 \%$ fetal bovine serum (FBS) at $37^{\circ} \mathrm{C}$ with $5 \% \mathrm{CO}_{2}$. Insulin resistance (IR) was induced in HepG2 cells as described previously, with slight modifications $[52,53]$. To stimulate with insulin, cells were incubated in serum-free DMEM for $6 \mathrm{~h}$, and then treated with $0.5,1,5$, and $10 \mu \mathrm{mol} / \mathrm{L}$ insulin for $24-60 \mathrm{~h}$, as indicated. The media were then replaced, and cells were cultured in DMEM without phenol red for $24 \mathrm{~h}$. The glucose content in the culture supernatant was measured using a GOD-POD assay, and cell counts and viability were determined by MTT assay. Cell viability $\left(\mathrm{OD}_{\mathrm{MTT}}\right)$ was used to normalized glucose consumption (glucose consumption/ $\mathrm{OD}_{\mathrm{MTT}}$ ).

To select stable induction conditions, cells were treated with insulin for different times, and were then cultured in normal media containing no insulin for $48 \mathrm{~h}$. Media were again replaced, and the cells were cultured for an additional $24 \mathrm{~h}$ in DMEM without phenol red. The glucose consumption was then measured, as described above. Relative glucose consumption (the ratio of glucose consumption in HepG2/IR cells and the corresponding control HepG2 cells) was determined in cells that had been induced, and those that had been induced and then cultured for $48 \mathrm{~h}$. The stability of the acquired IR was then determined by assessing whether the relative glucose consumption was stable after $48 \mathrm{~h}$.

The HepG2/IR cells were treated with different concentration of Pioglitazone Hydrochloride (PH) for $24 \mathrm{~h}$ to reverse IR, and then cultured in DMEM without phenol red for 24 $\mathrm{h}$ to measure glucose consumption. Glucose consumption was compared before and after reversing IR to optimize the concentration of $\mathrm{PH}$.

MTT assay. The viability of HepG2 cells under varying conditions was assessed using an MTT assay. For cellular cytotoxicity assays, $1 \times 10^{5}$ cells $/ \mathrm{mL}$ were plated in to 96-well plates and treated with $0-40 \mathrm{mmol} / \mathrm{L}$ Adriamycin (ADM; Sigma-Aldrich) for $24 \mathrm{~h}$; cytotoxicity was then assessed using MTT assays. MTT was also used in glucose consumption assays to calculate cell number so that glucose consumption could be normalized to cell number. HepG2 cells were treated with insulin, as indicated, to standardize glucose consumption. Cells were then cultured in DMEM containing 10\% FBS and $0.5 \mathrm{mg} / \mathrm{mL}$ MTT (Sigma-Aldrich) for $4 \mathrm{~h}$, before 10\% SDS was added and cells were incubated for an additional $12 \mathrm{~h}$. The absorbance at $570 \mathrm{~nm}\left(\mathrm{OD}_{\mathrm{MTT}}\right)$ was then measured using a Powerwave X plate reader (Bio-Tek, USA).

Glucose oxidase-peroxide enzyme (GOD/POD) assay. HepG2 cells were stimulated with insulin, as described above. Cells were then washed with PBS and incubated with DMEM 
$\left(\mathrm{pH}\right.$ 6.0) at $37^{\circ} \mathrm{C}$ for $20 \mathrm{~min}$. They were again washed twice with cold PBS, and cultured in DMEM without phenol red for $24 \mathrm{~h}$. Media were then removed, and the GOD-POD assay was used to measure glucose levels in the media and thus calculate glucose consumption. To eliminate the influence of cell proliferation, the $\mathrm{OD}_{\mathrm{MTT}}$ was measured so that glucose consumption could be normalized to cell number. Therefore, the normalized glucose consumption was defined as glucose consumption / OD ${ }_{\text {MTT. }}$.

Periodic acid-Schiff reaction (PAS) assay. The PAS assay was used to assess glycogen synthesis [54]. Briefly, slides of cells were treated with 0,1 , or $5 \mu \mathrm{mol} / \mathrm{L}$ insulin for 36 and $48 \mathrm{~h}$, fixed in $10 \%$ formaldehyde, incubated with $1 \%$ periodate solution, washed, and then incubated in the dark with Schiff reagent for $20 \mathrm{~min}$ at $60^{\circ} \mathrm{C}$. The reactions were terminated once the color of the dye had changed from pink to purple-red. Variations in optical density (as a measure of glycogen synthesis) were then analyzed using AX80 optical microscopy (Olympus, Japan).

ER and mitochondrial stress. The morphological features associated with ER and mitochondrial stress were assessed using electron microscopy. Briefly, cells were treated with 0 , 1 , or $5 \mu \mathrm{mol} / \mathrm{L}$ insulin for 36 or $48 \mathrm{~h}$, and immobilized in $3 \%$ glutaraldehyde. The ultrastructure of the ER and mitochondria were then observed using JEM 1230 transmission electron microscopy (JEOL, Japan).

Flow cytometric analysis (FCM). To assess the expression of InsR, HepG2 cells were incubated with InsR-FITC (Invitrogen, USA). Cells were treated without (control) or with 1 or $5 \mu \mathrm{mol} / \mathrm{L}$ insulin for $36 \mathrm{~h}$ or $48 \mathrm{~h}$, harvested, and incubated with the appropriate antibodies for $30 \mathrm{~min}$. Protein expression was then detected using an Epics XL-4 flow cytometer (Beckman-Coulter, USA). To detect the efflux function of P-gp, cells were collected, incubated with $30 \mathrm{mmol} / \mathrm{L}$ Adriamycin (which is a specific substrate for P-gp; Sigma-Aldrich) for $30 \mathrm{~min}$, and then analyzed by flow cytometry. The weaker the fluorescence intensity, the stronger the activity of the efflux pump.

Flow cytometry was also used to assess the levels of reactive oxygen species (ROS) and mitochondrial membrane potential (MMP). For ROS, cells were labeled with $0.1 \mathrm{mmol} / 1 \mathrm{DCFH}-$ DA (Sigma-Aldrich). In the presence of ROS, DCFH-DA gets oxidized into fluorescent DCF; this allows ROS levels to be determined indirectly using flow cytometry. To assess MMP, cells were cultured with $15 \mu \mathrm{g} / \mathrm{mL}$ Rhodamine 123 (SigmaAldrich) for $30 \mathrm{~min}$. Rhodamine 123 is a fluorescent lipophilic cationic compound that is sequestered in the inter-membrane space of active mitochondria in inverse proportion to MMP. Therefore, a more negative MMP results in the accumulation of more rhodamine 123 , leading to an increased fluorescence signal that can be detected by flow cytometry.

Real-time quantitative RT-PCR. Total RNA was extracted from cells using TRIzol reagent (Invitrogen, New Zealand), and was used to derive cDNA. All primers used for the PCR amplification of $\beta$-actin, Ins $R$, and $m d r 1$ genes were designed and synthesized by Takara. The expression of the genes was then analyzed using a Rotor-Gene 3000 quantitative PCR amplifier (Cobette, Australia).

Western blotting. Briefly, HepG2 cells treated as indicated were lysed, and the protein concentrations were assessed using the Bradford assay (Roche). Proteins were separated using SDS-PAGE electrophoresis, and transferred to PVDF membranes. Membranes were blocked with non-fat milk and probed with primary antibodies (anti-GRP78, anti-pPERK, anti-P-gp, or anti- $\beta$-actin) followed by IRDye $800 \mathrm{CW}$ or IRDye700DX-conjugated secondary antibodies (LI-COR, USA). Antibody-bound protein bands on the immunoblots were then visualized using an Odyssey double-color infraredlaser imaging system (LI-COR). Relative expression (average infrared fluorescence intensity of the target protein / $\beta$-actin) was then calculated to reflect true protein expression.

Statistical analysis. Data are expressed as means \pm SD. Statistical and graphical analyses were performed using Student's $t$-tests and SPSS 15.0 .

\section{Results}

Insulin resistance was induced by insulin in HepG 2 cells. HepG2 cells were treated with insulin $(0.5-10 \mu \mathrm{mol} / \mathrm{L})$ for varying times to induce insulin resistance. Treatment with insulin significantly decreased the relative glucose consumption in a dose- and time-dependent manner compared with control $(P<0.05$ and $P<0.01$, respectively). This was particularly evident in cells treated with $10 \mu \mathrm{mol} / \mathrm{L}$ for $60 \mathrm{~h}$, which were very unhealthy (Fig. 1A). Based on cell growth and glucose consumption, conditions of 1 or $5 \mu \mathrm{mol} / \mathrm{L}$ insulin for $36 \mathrm{~h}$ and $48 \mathrm{~h}$ were selected for the HepG2/IR cells.

Defects in glucose metabolism in insulin resistant cells are manifested as reduced glycogen synthesis, and so we used PAS staining to measure glycogen synthesis. Microscopic evaluation of PAS-stained cells revealed that HepG2/IR cells were shallow and more sunken than HepG 2 cells, particularly in those treated with $5 \mu \mathrm{mol} / \mathrm{L}$ insulin for $48 \mathrm{~h}$ (Fig. 1B). The optical density of intracellular glycogen after treatment with 1 and $5 \mu \mathrm{mol} / \mathrm{L}$ insulin decreased to 21.15 and $26.92 \%$, respectively, in HepG2/IR cells treated for $36 \mathrm{~h}$ compared with control, and 35.19 and $50.00 \%$ after $48 \mathrm{~h}$ (Fig. 1B). These data confirm that insulin resistance is associated with decreased glycogen synthesis in HepG2/IR cells.

When gene expression was studied using qRT-PCR, InsR was highly expressed in HepG2 cells, but downregulated in HepG2/IR cells. Specifically, treatment with 1 and $5 \mu \mathrm{mol} / \mathrm{L}$ insulin for 36 or $48 \mathrm{~h}$ resulted in significantly decreased expression of InsR at both the mRNA and protein levels. The InsR mRNA levels in HepG2/IR cells after treatment with 1 and $5 \mu \mathrm{mol} / \mathrm{L}$ insulin decreased to 38.36 and $49.71 \%$ of the control levels at $36 \mathrm{~h}$, and 16.67 and $28.33 \%$ at $48 \mathrm{~h}$, respectively (Fig. 1C). The equivalent decline in INSR protein levels detected using FCM was consistent with the mRNA changes. Specifically, the mean fluorescence intensity (MFI) of INSR declined from 20.40 (control) to $9.57(1 \mu \mathrm{mol} / \mathrm{L}$ insulin) and $3.66(5 \mu \mathrm{mol} / \mathrm{L}$ 
A

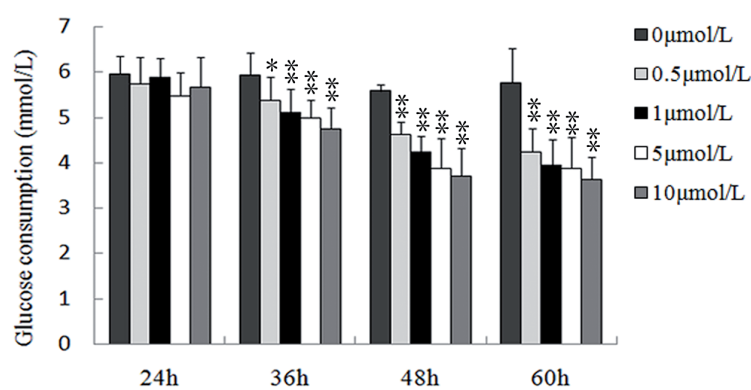

Eestablishment of HepG2/IR cell model

B

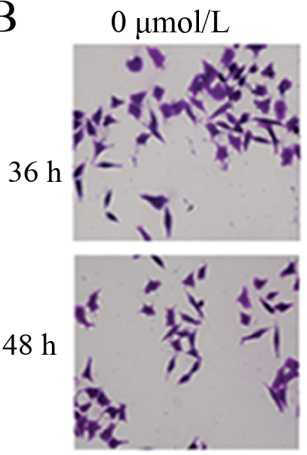

$1 \mu \mathrm{mol} / \mathrm{L}$

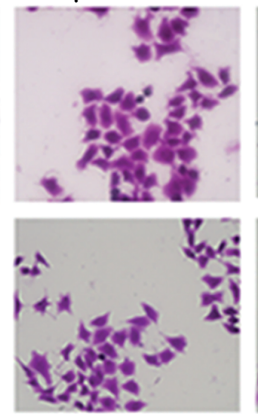

$5 \mu \mathrm{mol} / \mathrm{L}$
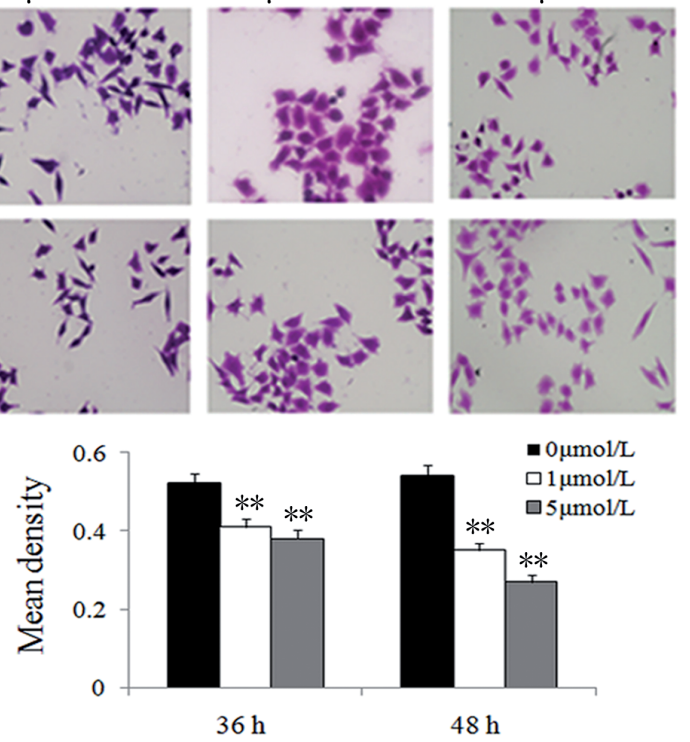

The glycogen synthesis of HepG2 cells induced by insulin

$\mathrm{E}$

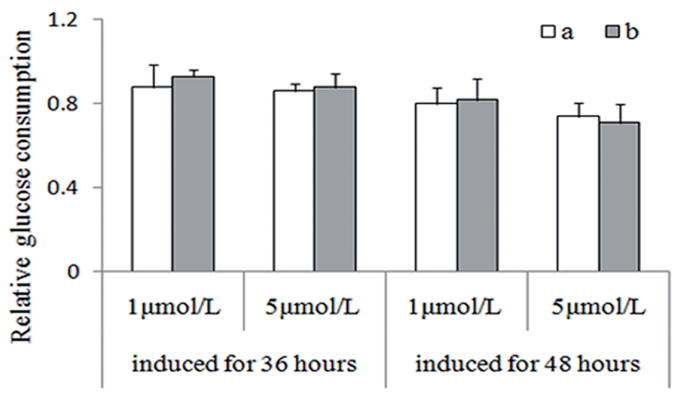

The stability of insulin resistance in HepG2 cells induced by insulin

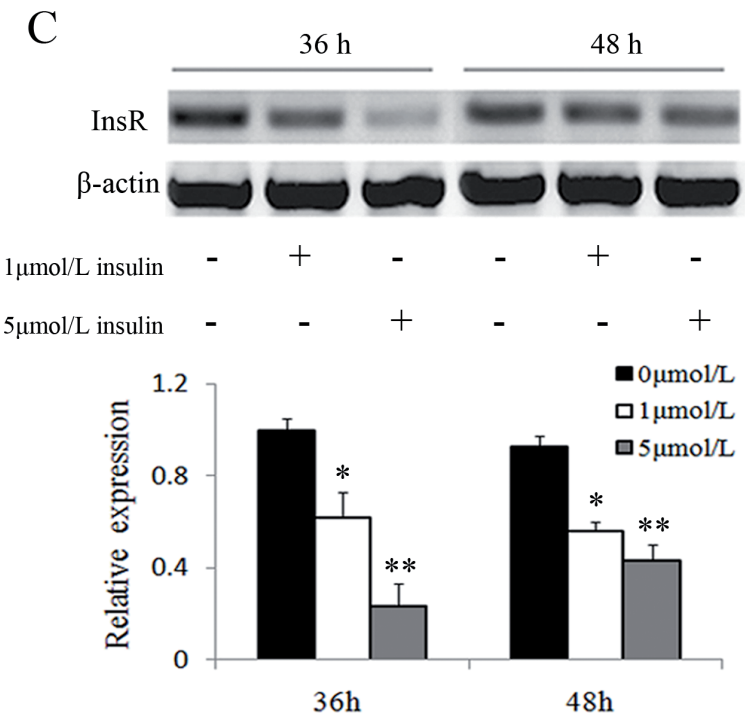

Relative expression of InsR

D
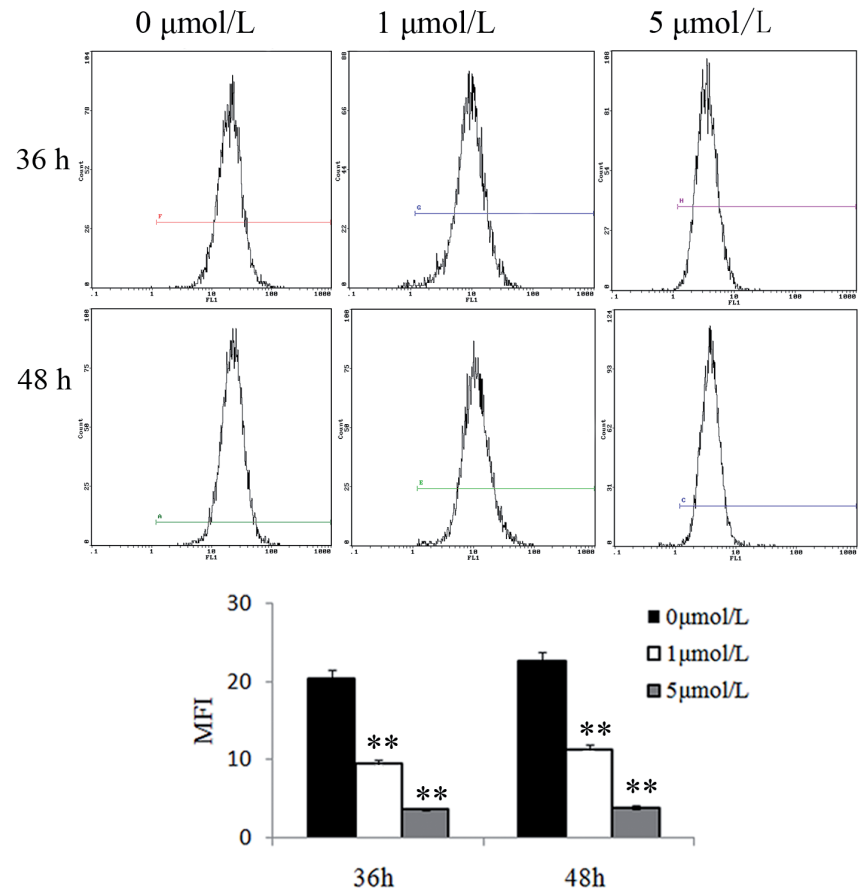

Relative expression of INSR protein

Figure 1. Resistance induction with insulin resistance in HepG2 cells. (A) Glucose consumption in insulin-induced HepG2 cells. The HepG2 cells were induced without or with insulin $(0.5-10 \mu \mathrm{mol} / \mathrm{L})$ for 24 to $60 \mathrm{~h}$ and the glucose concentrations of the cells were measured by GOD-POD assay. (B) Glycogen synthesis was measured using PAS staining in HepG2 cells and HepG2/IR cells (HepG2 cells treated with 1 or 5 mmol/L insulin for 36 or $48 \mathrm{~h}$ ) (the upper part), Photodensitometry revealed statistical differences in glycogen synthesis between HepG2/IR cells and control (the lower part). (C) Down-regulated expression of InsR mRNA in HepG2/IR cells, established from the HepG2 cells induced by $1 \mu \mathrm{mol} / \mathrm{L}$ and $5 \mu \mathrm{mol} / \mathrm{L}$ insulin for $36 \mathrm{~h}$ and $48 \mathrm{~h}$ respectively, measured by $\mathrm{QRT}$-PCR(the lower part) and the amplification products were separated on $3 \%$ agarose gels(the upper part). (D) The decreased expression of InsR protein in HepG2/IR cells, from the HepG2 cells induced by $1 \mu \mathrm{mol} / \mathrm{L}$ and $5 \mu \mathrm{mol} / \mathrm{L}$ insulin for $36 \mathrm{~h}$ and $48 \mathrm{~h}$, respectively, measured by Flow cytometry (the upper part), and the mean fluorescence intensity (MFI) of InsR expression was used to judge the expressing intension of InsR in HepG2/IR cells (the lower part) (E) The stability of HepG2/IR cells was $>48 \mathrm{~h}$. Relative glucose consumption was compared between cells that had been induced (a), and those that had been induced and then cultured for 48 (b). Experiments were repeated three times with similar results, and the results are presented as mean \pm SD of triplicate experiments. ${ }^{*} P<0.05$; ${ }^{\star} P<0.01$, compared with control. 


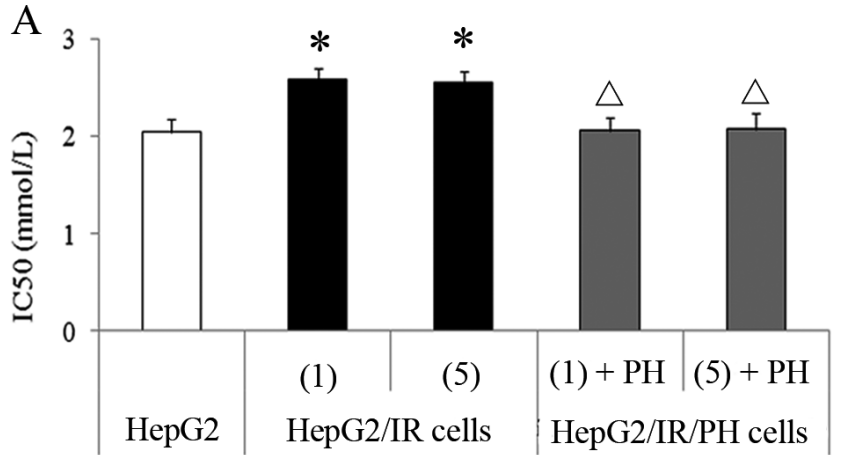

B

The sensitivity to ADM

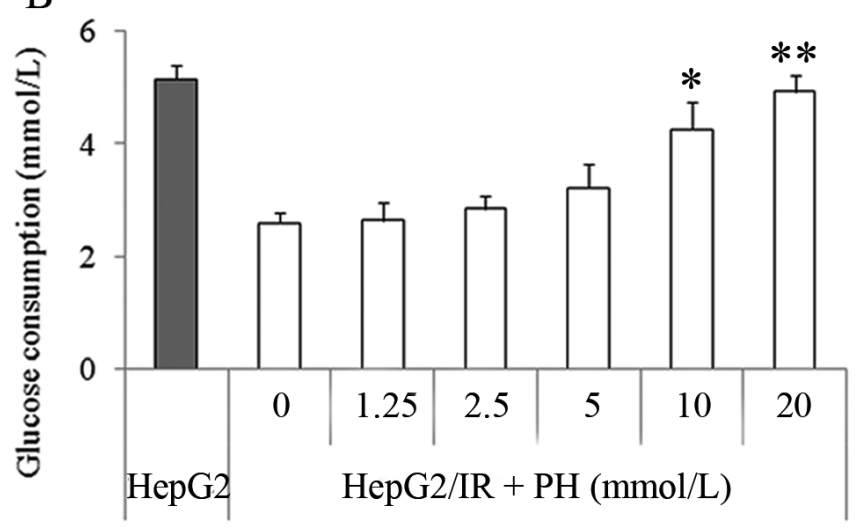

The insulin resistance reversed by $\mathrm{PH}$

Figure 2. HepG2/IR cells are tolerant to Adriamycin due to insulin resistance. (A) HepG2/IR cells, established from induction with $1 \mu \mathrm{mol} / \mathrm{L}(1)$ and $5 \mu \mathrm{mol} / \mathrm{L}(5)$ insulin for $48 \mathrm{~h}$ respectively, and HepG2 cells were treated with $0.25-40.00 \mathrm{mmol} / \mathrm{L}$ Adriamycin for $48 \mathrm{~h}$, and an MTT assay was used to assess the viability of HepG2/IR and HepG2 cells and the IC50 values of Adriamycin were calculated. For the reversion of insulin resistance, the HepG2/IR(1) and HepG2/IR(5) cells were pre-treated with $10 \mathrm{mmol} / \mathrm{L}$ pioglitazone for $24 \mathrm{~h}$ before adriamycin administration, which were indicated as (1) $+\mathrm{PH}$ and (5) $+\mathrm{PH}$ respectively in the figure. (B) HepG2/IR cells, formed via induction of $5 \mu \mathrm{mol} / \mathrm{L}$ insulin for $48 \mathrm{~h}$, were treated with 0-20 $\mu \mathrm{mol} / \mathrm{L}$ pioglitazone for $24 \mathrm{~h}$, and Glucose consumption was assessed by GOD-POD assay, and HepG2 cells were employed as the control cells. Experiments were repeated three times with similar results and the results are presented as mean $\pm \mathrm{SD}$ of triplicate experiments. Significance vs. HepG2 cells: ${ }^{\star} P<0.05 ;{ }^{*} P<0.01$. Significance vs. HepG2/IR cells: $\Delta P<0.05 ; \Delta \Delta P<0.01$.

insulin) at $36 \mathrm{~h}$, and from 22.70 (control) to $11.30(1 \mu \mathrm{mol} / \mathrm{L}$ insulin) and $3.89(5 \mu \mathrm{mol} / \mathrm{L}$ insulin $)$ at $48 \mathrm{~h}$, with a reduction in expression ranging from $50.2-82.9 \%$ (Fig. 1D). The results above showed that the expression of InsR gene in HepG2/IR cells slightly appeared a stressful increase along with the extension of induction by high concentration of insulin, but this slight increase does not change the fact that the expression of InsR gene in HepG2/IR cells is down-regulated significantly, which support that insulin resistance could be induced in Hepg2 cells by treatment with insulin.

Next, relative glucose consumption (glucose consump-

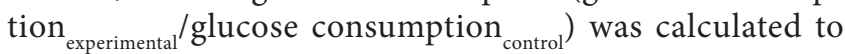

observe the stability of the induced IR. No obvious change was observed between induced cells and those that were cultured without insulin for an additional $48 \mathrm{~h}$ after induction (Fig. 1E).

The reduced sensitivity of HepG2/IR cells to Adriamycin. Adriamycin is a cytotoxic drug widely used in clinical chemotherapy as a treatment for hepatocellular carcinoma. It functions by entering cells, intercalating in to DNA or RNA, and inhibiting nucleic acid synthesis. To determine whether HepG2/IR cells were more resistant to chemotherapy drugs, MTT assays was used to assess the susceptibility of HepG2/ IR and HepG2 cells to $0.25-40 \mu \mathrm{mol} / \mathrm{L}$ Adriamycin, and accordingly, the $50 \%$ inhibitory concentration (IC50) and the drug-resistance value was calculated. Compared with HepG2 cells, HepG2/IR cells, formed by induction with 1 and $5 \mu \mathrm{mol} / \mathrm{L}$ insulin for $48 \mathrm{~h}$, were insensitive to $\mathrm{ADM}(P<0.05)$, and the IC50 value was increased significantly by 1.27 -times and 1.24-times, respectively (Fig. 2A). This suggests that HepG2/ IR cells were much more resistant to chemotherapeutics than their parent cells.

Pioglitazone hydrochloride (PH) is a widely used insulin sensitizer that increases glucose utilization in cells, and reverses insulin resistance. Therefore, we treated HepG2/IR cells (induced with $5 \mu \mathrm{mol} / \mathrm{L}$ insulin for $48 \mathrm{~h}$ ) with $\mathrm{PH}$ to reverse intracellular insulin resistance. Glucose consumption was positively correlated with $\mathrm{PH}$, and glucose consumption in cells treated with concentrations $\geq 10 \mathrm{mmol} / \mathrm{L}$ was comparable to HepG2 cells without PH (Fig. 2B).

Next, we determined if the reversing insulin resistance in HepG2/IR cells treated with PH modulated the susceptibility of cells to Adriamycin. HepG2/IR cells were treated with $10 \mathrm{mmol} / \mathrm{L} \mathrm{PH}$ for $24 \mathrm{~h}$, and the sensitivity to Adriamycin was assessed by MTT assay. The IC50 value decreased by 21.32 and $18.82 \%$ in cells that had been induced by 1 and $5 \mu \mathrm{mol} / \mathrm{L}$ insulin for $48 \mathrm{~h}$, respectively, which was comparable to HepG2 cells that had not been treated with insulin (Fig. 2A). This suggests that insulin resistance in HepG2 cells caused tolerance to chemotherapy drugs.

Insulin resistance was accompanied by ER stress in HepG2/IR cells. It is well known that insulin resistance leads to increased blood sugar, which causes pancreatic beta cells to secrete more insulin. This leads to hyperinsulinemia, and potentiates insulin resistance. Recent studies suggested that the persistent presence of insulin could stimulate mitochondria to produce reactive oxygen species (ROS), which then induces ER stress $[25,26]$. In this study, the dilatation and degranulation of ER was observed in HepG2/IR cells under the electron microscope. In addition, mitochondrial cristae were disordered and swollen, and convexes on the cell surface were increased in number and enlarged. It was interesting that these changes of ER mentioned above could be reversed and normalized by treatment with $10 \mathrm{mmol} / \mathrm{L} \mathrm{PH}$ for $24 \mathrm{~h}$, and this suggests that ER stress was activated in HepG2/IR cells accompanied with the occurrence of insulin resistance. (Fig. 3A). 
A

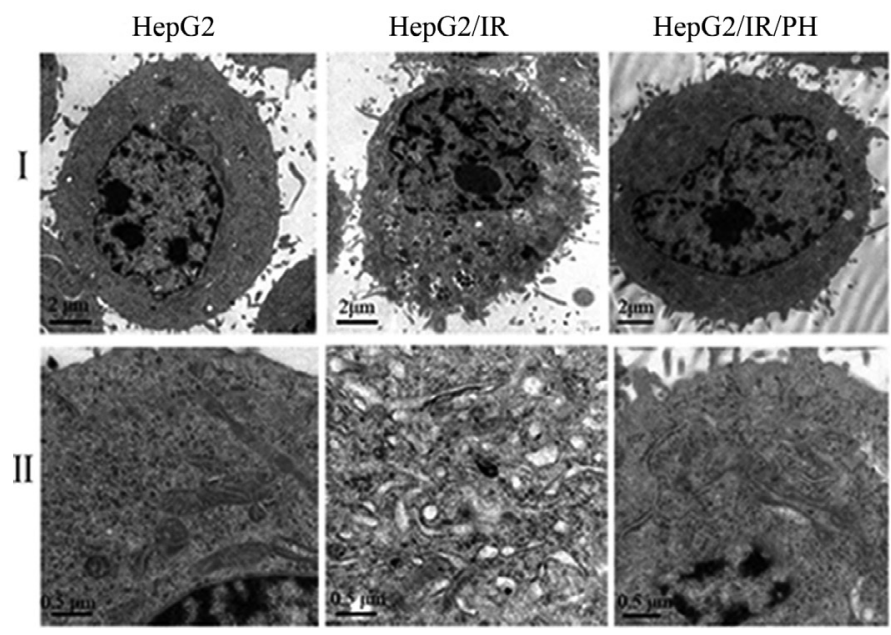

The morphological changes

B

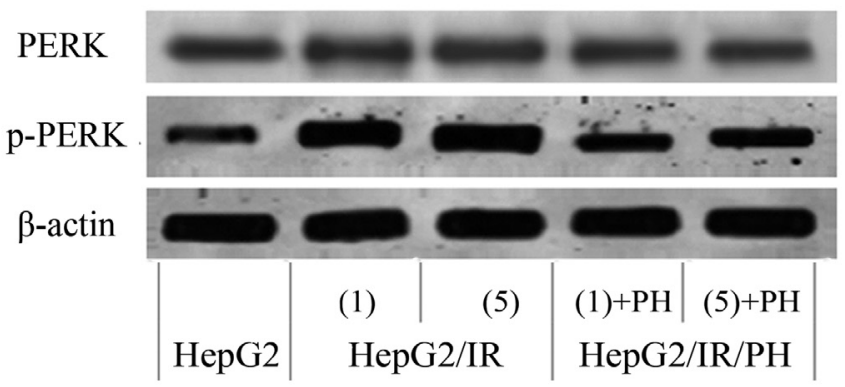

$\mathrm{C}$

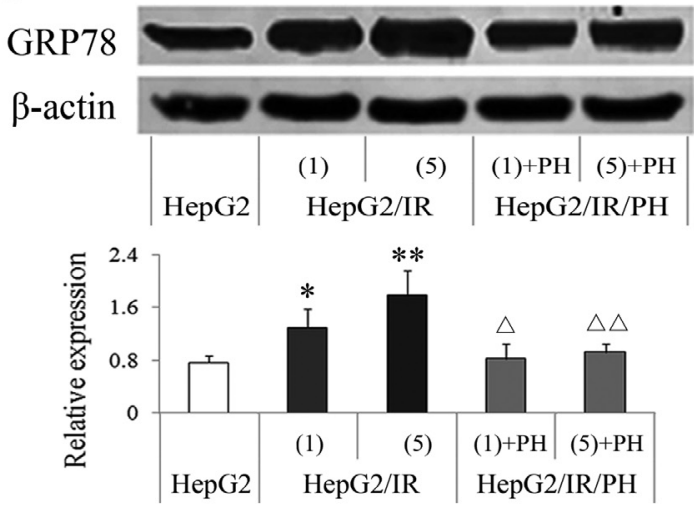

Relative expression of GRP78 protein

D
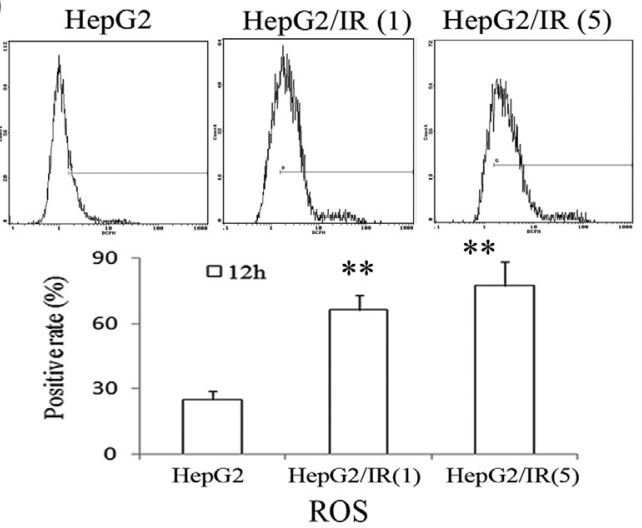

$\mathrm{E}$
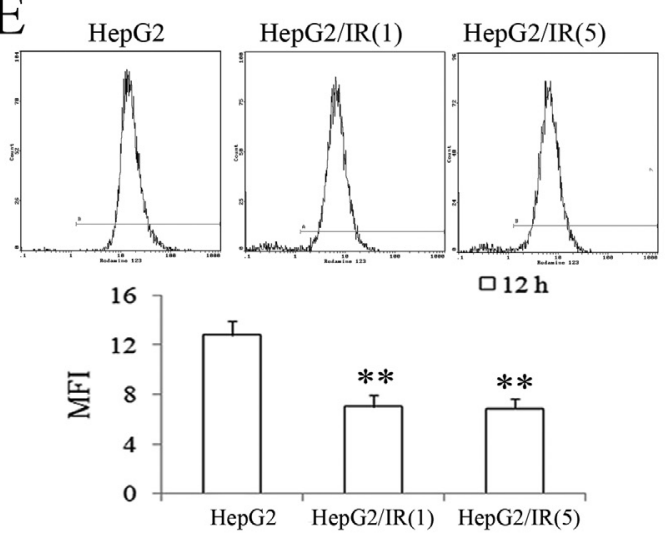

MMP

Figure 3. Insulin-resistant hepatoma cells exhibit endoplasmic reticulum stress. (A) Morphological changes in the ER and mitochondria of HepG2/IR and HepG2/IR/PH cells, as observed by electron microscopy. The ER exhibited obvious expansion and degranulation. Mitochondria were swollen, the inner and outer membranes were fused, and cristae formation was reduced, and those changes mentioned above could be reversed by insulin sensitizer Pioglitazone hydrochloride (PH). (I) $8000 \times$ magnification; (II) 40,000 $\times$ magnification. (B) Expression of p-PERK and PERK in HepG2 cells and HepG2/IR cells. The HepG2 cells and the HepG2/IR cells, formed from induction with insulin for $48 \mathrm{~h}$ respectively, and the HepG2/IR cells reversed by Pioglitazone (showed as HepG2/IR/PH) were extracted with BCA protein assay, and the expression and phosphorylation of PERK were assessed with western blotting. (C) Expression of GRP78 in HepG2, HepG2/IR and HepG2/IR/PH cells. Indicated as the same as in (B), the expression of GRP78, an endoplasmic reticulum chaperone and hallmark of endoplasmic reticulum stress, was examined with western blotting. The expression of GRP78 increased in HepG2/IR cells compared with HepG2 cells and also could be reversed by PH. (D) The production of ROS was increased during the first $12 \mathrm{~h}$ of developing insulin resistance as measured by flow cytometry (FCM). (E) MMP was also reduced during the first $12 \mathrm{~h}$ of developing insulin resistance, as assessed by FCM. hepg2/ IR(1) and hepg2/IR(5) stands for the HepG2/IR cells established from induction with $1 \mu \mathrm{mol} / \mathrm{L}$ and $5 \mu \mathrm{mol} / \mathrm{L}$ insulin, respectively. HepG2/IR/PH means that the corresponding HepG2/IR cells reversed by $10 \mathrm{mmol} / \mathrm{L} \mathrm{PH}$ for $24 \mathrm{~h}$. Experiments were repeated three times with similar results, and the results are presented as mean $\pm \mathrm{SD}$ of triplicate experiments. ${ }^{*} P<0.05 ;{ }^{* *} P<0.01$, compared with control. Significance vs. HepG2/IR cells: $\Delta P<0.05 ; \Delta \Delta P<0.01$. 
Protein kinase R- like ER kinase (PERK) is a type I transmembrane protein located in the endoplasmic reticulum, and is a major marker of ER stress. The autophosphorylation of PERK (p-PERK) leads to its activation during early ER stress, which inhibits protein synthesis and promotes cell survival [15]. Therefore, we assessed the expression of PERK and p-PERK in HepG2/IR cells using a specific antibodies to the activated/phosphorylated form of PERK (p-PERK) and total PERK. The increasing of p-PERK was accompanied by decreasing of total PERK in HepG2/IR cells, and the ratio of p-PERK/PERK was increased by 1.59 -folds for induction with $1 \mu \mathrm{mol} / \mathrm{L}$ insulin, and by 1.74 -folds for induction with $5 \mu \mathrm{mol} / \mathrm{L}$ insulin (Fig. 3B). These results confirmed that early ER stress was active in HepG2/IR cells. Whether the insulin resistance was closely related with ER stress, the HepG2/IR cells were treated with $10 \mathrm{mmol} / \mathrm{L} \mathrm{PH}$ for $24 \mathrm{~h}$, specified as HepG2/IR/ PH cells, and the expression of total PERK was elevated along with the reduction of p-PERK/PERK by $54.19 \%$ and $53.44 \%$,

A

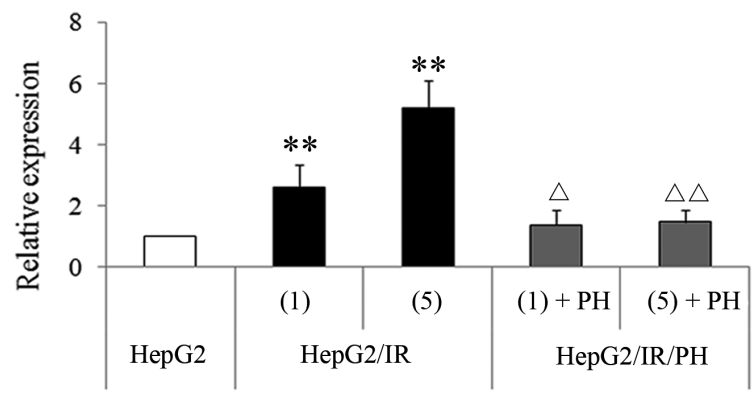

Relative expression of mdr1

$\mathrm{C}$
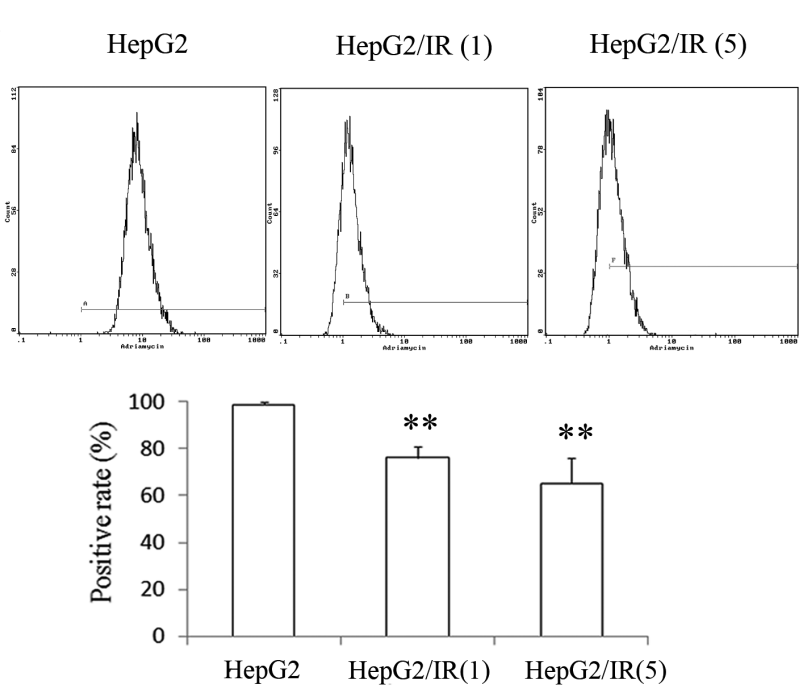

The efflux function of P-gp respectively, compared with the corresponding HepG2/IR cells (Fig. 3B). That is, reversing insulin resistance by Pioglitazone could inhibit the ER stress via reducing the autophosphorylation of PERK in HepG2/IR cells.

Glucose regulated protein 78 (GRP78/Bip), an endoplasmic reticulum chaperone, is an additional major marker of ER stress. The levels of GRP78 protein in HepG2/IR cells were assessed using western blotting, and were increased by 69.74 and $134.21 \%$ in the cells induced with 1 and $5 \mu \mathrm{mol} / \mathrm{L}$ insulin for $48 \mathrm{~h}$, respectively. Similarly, $\mathrm{PH}$ reduced the expression of GRP78 by $36.43 \%$ and $48.32 \%$ in HepG2/IR/PH cells compared with its corresponding IR cells, respectively. These results confirm that ER stress in HepG2/IR cells led to the up-regulation of GRP78 (Fig. 3C).

Next we used FCM to measure reactive oxygen species (ROS) and mitochondrial membrane potential (MMP) during early insulin action $(12 \mathrm{~h})$ to clarify the relationship between ROS, MMP, and ER stress in HepG2/IR cells. The positive

B
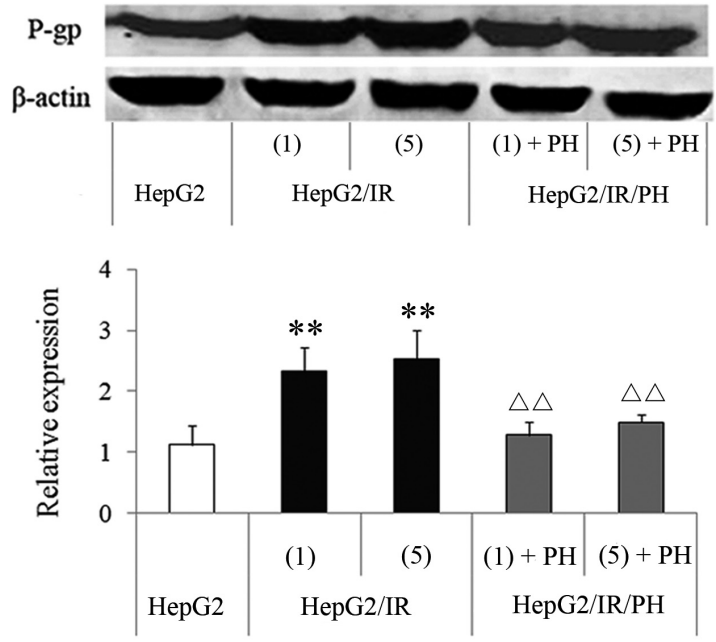

The relative expression of P-gp

Figure 4. The up-regulated expression and function of mdrl/P-gp in HepG2/ IR cells. (A) The mRNA expression of mdr1 in HepG2 cells, HepG2/IR cells and the HepG2/IR/PH cells was assessed by qRT-PCR method, and the relative expression of mdr1 gene was showed. (B) The expression of P-gp in HepG2 cells, HepG2/IR cells including HepG2/IR(1) and HepG2/IR(5) and PHreversed HepG2/IR cells (HepG2/IR/PH) was detected by western blotting(the upper part), and the average infrared fluorescence intensity of the bands was showed (the lower part). (C) The efflux function of the drug transporter P-gp in HepG2, HepG2/IR and HepG2/IR/PH cells. The above HepG2 cells, HepG2/ IR cells and HepG2/IR/PH cells were incubated with $30 \mathrm{mg} / \mathrm{L}$ Adriamycin for $30 \mathrm{~min}$, and then measured with flow cytometry (the upper part), and the mean intracellular fluorescence intensity was showed(the lower part). hepg2/ IR(1) and hepg2/IR(5) stands for the HepG2/IR cells established from induction with $1 \mu \mathrm{mol} / \mathrm{L}$ and $5 \mu \mathrm{mol} / \mathrm{L}$ insulin, respectively. HepG2/IR/PH means that the corresponding HepG2/IR cells reversed by 10mmol/L PH for $24 \mathrm{~h}$. Experiments were repeated three times with similar results, and the results are presented as mean $\pm S D$ of triplicate experiments. ${ }^{*} P<0.05$; ${ }^{*} P<0.01$, compared with control. Significance vs. HepG2/IR cells: $\Delta P<0.05 ; \Delta \Delta P<0.01$. 
rate of DCFH fluorescence, which reflects the levels of ROS, was increased by 163.75 and $208.37 \%$ in cells treated with 1 and $5 \mu \mathrm{mol} / \mathrm{L}$ insulin, respectively, compared with HepG2 cells (Fig. 3D). The Mean fluorescence intensity (MFI) of Rhodamine 123, which reflects MMP, were decreased by 45.39 and $46.17 \%$ in cells treated with 1 and $5 \mu \mathrm{mol} / \mathrm{L}$ insulin compared with control HepG2 cells (Fig. 3E). These data support the hypothesis that treatment with insulin results in acute increased ROS production and decreased MMP in HepG2/IR cells (Fig. 3E).

Our results suggest that the mechanism of ER stress in HepG2/IR cells is reduced stability of the mitochondrial membrane due to excessive ROS production at the early stage, which inhibits the ability of the ER to fold proteins correctly. This causes the accumulation of unfolded proteins in the endoplasmic reticulum, which activates PERK and upregulates ER chaperones such as GRP78. GRP78 can regulate the equilibrium of calcium in the ER and mitochondria by stimulating its re-absorption, reducing the aggregation of misfolded proteins and decreasing ER stress-induced apoptosis. Therefore, tumor cells can avoid ER stress-induced apoptosis by increasing the expression of GRP78 [14, 27-28].

Enhanced expression of the drug resistance gene $m d r 1$ in HepG2/IR cells. Adenosine triphosphate-binding cassette transporters ( $\mathrm{ABC}$ transporters) on the cell membrane play a key role in the formation of multi-drug resistance in tumor cells. The ABC transporter P-glycoprotein (P-gp), encoded by the ABCB1 ( $m d r 1)$ gene, is closely linked with MDR [29]. Its expression is influenced by nutrition and the metabolic state. It is also an endoplasmic reticulum chaperone that plays a role in ER stress by directly transporting misfolded proteins [2224]. Our data revealed that ER stress was activated in HepG2/ IR cells, and was accompanied by upregulated expression of the drug transporter P-gp. The mRNA expression of $m d r 1$ was 1.62-and 4.21 fold higher in HepG2/IR cells treated with 1 and $5 \mu \mathrm{mol} / \mathrm{L}$, respectively, compared with control HepG2 cells, as assessed by qRT-PCR (Fig. 4A). Comparable changes in the levels of P-gp were also detected, with increases of $107.14 \%$ (induced by $1 \mu \mathrm{mol} / \mathrm{L}$ insulin for $48 \mathrm{~h}$ ), and $126.79 \%$ (induced by $5 \mu \mathrm{mol} / \mathrm{L}$ insulin for $48 \mathrm{~h}$ ) (Fig. 4B). These data suggest that the MDR-related gene $m d r 1$ was upregulated in HepG2/IR cells.

To verify these observations, the expression of $m d r 1$ was assessed in HepG2/IR cells that had been reversed by treatment with $10 \mathrm{mmol} / \mathrm{L} \mathrm{PH}$ for $24 \mathrm{~h}$. The mRNA expression of $m d r 1$ was reduced by 47.33 and $71.79 \%$ in cells induced with 1 and $5 \mu \mathrm{mol} / \mathrm{L}$ insulin, respectively, compared with HepG2/IR cells (Fig. 4A); similarly, the levels of P-gp were also reduced by $44.83 \%$ and $41.34 \%$, respectively, compared with HepG2/IR cells (Fig. 4B). Therefore, $\mathrm{PH}$ reduced the expression of $m d r 1$ in HepG2/IR cells by reversing insulin resistance, confirming that the ER chaperone may play a role in drug resistance in HepG2/IR cells.

Finally, we determined whether the overexpression of P-gp modulated the efflux capacity of HepG2/IR cells. Therefore, used FCM to compare the efflux of Adriamycin in HepG2/IR and HepG2 cells. After incubating cells with $30 \mathrm{mmol} / \mathrm{L}$ ADM for $30 \mathrm{~min}$, the content of Adriamycin was reduced by 22.87 and $33.81 \%$ in HepG2/IR cells treated with 1 and $5 \mu \mathrm{mol} / \mathrm{L}$ insulin for $48 \mathrm{~h}$ compared with HepG2 cells (Fig. 4C). This suggests that the efflux capacity of ADM was increased in HepG2/IR cells. Therefore, we speculate that HepG2/IR cells exhibited an increased number and function of intracellular drug transporters, and that enhanced efflux ability promoted tolerance to chemotherapy drugs.

\section{Discussion}

This study reports that ER stress occurs in HepG2/IR cells, and that the overexpression of the drug transporter P-gp mediates resistance to the chemotherapy drug Adriamycin. Disorders in glucose metabolism cause a reduced susceptibility of patients with malignant tumors to insulin and IR; IR is also a risk factor for a variety of malignant tumors. In addition, treating IR can lower tumor morbidity, delay tumorigenesis, and enhance the sensitivity to chemotherapeutic agents [4-13]. In a further study, insulin resistance was accompanied by hyperinsulinemia, whereas insulin promoted tumor cell proliferation, inhibited apoptosis, and reduced the efficacy of antitumor drugs [22]. Diabetes was also associated with the upregulated expression of numerous multi-drug resistance genes [30], which may promote tumor cell survival. However, the mechanism by which IR promotes the occurrence and development of malignant tumors, as well as drug resistance, is unclear.

The liver is one of the main target organs of insulin action, and can also produce glucose. As such, insulin resistance occurs when liver cells become insensitive to insulin $[1,2]$. HepG2 cells are hepatocellular carcinoma cells with the characteristics of normal liver cells, and high levels of expression of InsR [2]. As such, treating them with insulin can induce a model of insulin resistance. In this study, IR occurred in HepG2 cells treated with high concentrations of insulin, resulting in lowered glucose uptake and reduced glycogen synthesis in HepG2/IR cells. The levels of InsR mRNA and protein were also decreased significantly, consistent with IR. In addition, the sensitivity of HepG2/IR cells to Adriamycin was significantly lower than HepG2 cells. However, the sensitivity to Adriamycin was increased after treatment with the insulin sensitizer pioglitazone hydrochloride, suggesting that insulin resistance was closely related to drug tolerance.

Previous studies suggested that IR requires ER stress. The insulin resistant state was accompanied by hyperinsulinemia and abnormal glucose metabolism, both of which can induce ER stress by stimulating mitochondria to produce ROS. ER stress then inhibits insulin and reduces the expression of GLUTs, exacerbating IR [1, 28, 31-36]. In this study, early IR was accompanied by increased production of intracellular ROS and decreased MMP, resulting in oxidative and ER stress. Electron microscopy images revealed that HepG2/IR cells 
exhibited dilatation and degranulation of the ER, whereas mitochondrial cristae were disordered and swollen, consistent with previous reports [14].

The UPR that occurs during ER stress allows cells to restore intracellular environmental homeostasis $[28,37]$. When the ER becomes damaged and cannot restore its normal functions, apoptosis is induced to eliminate the injured cell [38]. Additional studies in tumor models demonstrated that under conditions of ER stress, GRP78 maintains the internal environment within the tumor. This enhances the survival and invasiveness of the cancer cell, allowing it to escape immune surveillance, and reduces cytotoxic T cells. GRP78 also confers resistance to the apoptosis induced by antineoplastic drugs, modulating tumor growth and stimulating resistance to a broad-spectrum of treatments targeted at inducing caspasedependent apoptosis [16, 17, 28, 33-34]. In this study, insulin resistance was accompanied by increased activation of PERK and the upregulation of GRP78, suggesting that ER stress occurred during insulin resistance. Under normal conditions, hepatocellular carcinoma cells are not sensitive to chemoand radiotherapy, characterized by drug resistance and poor systemic effects of therapies. This may be due to the state of chronic stress caused by the liver tumor microenvironment, including underdeveloped vessels, anoxia, low glucose, and low $\mathrm{pH}[28,32-36,39-42]$.

$\mathrm{ABC}$ transporters on the cell membrane play a significant role in the drug-resistance of pathogens, and multi-drug resistance in tumors. P-gp, which is encoded by the $m d r 1$ gene, is an $\mathrm{ABC}$ transporter with an important role in drug resistance. It is predominantly localized to the plasma membrane, and actively transports substrates or drugs out of cells using energy released by the hydrolysis of ATP [43-45]. Additional studies revealed that P-gp could directly and indirectly regulate molecular metabolism, cell proliferation, and differentiation. The distribution and reverse drug transportation function of P-gp suggests that it plays a significant role in the absorption, distribution, metabolism, clearance, and sensitivity to drugs [45-48]. In tumor cells, P-gp can directly transport misfolded proteins by excreting antineoplastic drugs, or participate in ER stress by interacting with ER chaperones. It could also inhibit the UPR and caspase-induced cell death [24,49-50]. Consistent with these data, our study revealed that the expression of $m d r 1$ mRNA and P-gp was increased significantly in HepG2/IR cells compared with normal HepG2 cells. In addition, the intracellular levels of Adriamycin in HepG2/IR cells were decreased, consistent with enhanced P-gp efflux action.

Pioglitazone hydrochloride ( $\mathrm{PH})$ is a widely used insulin sensitizer that reduces insulin resistance and increases glucose utilization in skeletal muscle and liver tissues [51]. PH significantly decreased the expression of GRP78, p-PERK, and P-gp, and also increased the sensitivity to ADM, confirming that ER stress had a close relationship with insulin resistance.

In conclusion, HepG2/IR cells had significantly improved tolerance to $\mathrm{ADM}$ via ER stress and the increased expression and function of $m d r 1$ and P-gp. Importantly, the tolerance of HepG2/IR cells to ADM could be reversed by treatment with $\mathrm{PH}$, which resulted in the downregulated expression of GRP78, P-gp, and activated PERK. The mechanism by which HepG2/IR cells are resistant to ADM may be that insulin resistance contributes to ER stress and the upregulation of GRP78, which promotes correct protein folding and protein transport, a stable intracellular environment, and resistance to apoptosis. IR could also stimulate the expression of $m d r 1$ via ER stress, resulting in anti-apoptotic effects mediated by the excretion of chemotherapeutic agents. In addition, P-gp and the transfer of un- or mis-folded proteins further inhibited the development of ER stress, suppressed ER stress-induced apoptosis, and promoted the tolerance of hepatocarcinoma cells to chemotherapeutic agents. In future studies, we will confirm our findings and hypotheses in animal models in vivo.

Acknowledgements: This work was supported by the Fundamental Research Funds for the Central Universities(Grant No: lzujbky-2013142), the project of youth science and technology fund of Gansu province of China(Grant No: 1308RJYA05) and the Program for Changjiang Scholars and Innovative Research Team in University (PCSIRT No: IRT1137)

\section{References}

[1] DRAZNIN B. Molecular mechanisms of insulin resistance: serine phosphorylation of insulin receptor substrate-1 and increased expression of p85a the two sides of a coin. Diabetes 2006; 55: 2392-2397. http://dx.doi.org/10.2337/db06-0391

[2] LECLERCQ IA, MORAIS ADS, SCHROYEN B, VAN HUL N, GEERTS A. Insulin resistance in hepatocytes and sinusoidal liver cells: Mechanisms and consequences. J Hepatol 2007; 47: 142-156. http://dx.doi.org/10.1016/j.jhep.2007.04.002

[3] WILCOX G. Insulin and insulin resistance. Clin Biochem Rev 2005; 26: 19-39.

[4] YOSHIKAWA T, NOGUCHI Y, DOI C, MAKINO T, NOMURA K. Insulin resistance in patients with cancer:relationships with tumor site, tumor stage, body-weight loss, acute-phase response, and enery expenditure. Nutrition 2001; 17: 590-593. http://dx.doi.org/10.1016/S0899-9007(01)00561-5

[5] KEKU TO, LUND PK, GALANKO J, SIMMONS JG, WOOSLEY JT, et al. Insulin resistance, apoptosis, and colorectal adenoma risk. Cancer Epidemiol Biomarkers Prev 2005; 14: 2076-2081. http://dx.doi.org/10.1158/1055-9965.EPI-05$\underline{0239}$

[6] VERHEUS M, PEETERS PH, RINALDI S, DOSSUS L, BIESSY C, et al. Serum C-peptide levels and breast cancer risk: results from the European Prospective Investigation into Cancer and Nutrition (EPIC). Int J Cancer 2006; 119: 659-667. http:// dx.doi.org/10.1002/ijc.21861

[7] WEIDERPASS E, PERSSON I, ADAMI HO, MAGNUSSON C, LINDGREN A, et al. Body size in different periods of life, diabetes mellitus, hypertension, and risk of postmenopausal endometrial cancer (Sweden). Cancer Causes Control 2000; 11: 185-192. http://dx.doi.org/10.1023/A:1008946825313 
[8] SOLIMAN PT, WU D, TORTOLERO-LUNA G, SCHMELER KM, SLOMOVITZ BM, et al. Association between adiponectin, insulin resistance, and endometrial cancer. Cancer 2006; 106: 2376-2381. http://dx.doi.org/10.1002/cncr.21866

[9] CUST AE, KAAKS R, FRIEDENREICH C, BONNET F, LAVILLE $M$, et al. Plasma adiponectin levels and endometrial cancer risk in pre-and postmenopausal women. J Clin Endocrinol Metab 2007; 92: 255-263. http://dx.doi.org/10.1210/ jc.2006-1371

[10] PERMERT J, IHSE I, JORFELDT L, VON SCHENCK H, ARNQUIST HJ, et al. Improved glucose metabolism after subtotal pancreatectomy for pancreatic cancer. Br J Surg 1993; 80: 1047-1050. http://dx.doi.org/10.1002/bjs.1800800841

[11] LIU J, KNEZETIC JA, STROMMER, PERMERT J, LARSSON J. The intracellular mechanism of insulin resistance in pancreatic cancer patients. J Clin Endocrinol Metab 2000; 85: $1232-1238$.

[12] TURATi F, TALAMini R, PELUCCHI C, POLESEL J, FRANCESCHI S, et al. Metabolic syndrome and hepatocellular carcinoma risk. Br J Cancer 2013; 108: 222-228. http:// dx.doi.org/10.1038/bjc.2012.492

[13] DONADON V, BALBI M, PEREIACCANTE A, CASARIN $\mathrm{P}$, ZANETTE G. Insulin resistance and hyperinsulinemia in patients with chronic liver disease and hepatocellular carcinoma. Clin Med Endocrinol Diabetes 2009; 2: 25-33.

[14] YOSHIUCHI K, KANETO H, MATSUOKA T, KOHNO K, IWAWAKI T, et al. Direct monitoring of in vivo ER stress during the development of insulin resistance with ER stressactivated indicator transgenic mice. Biochem Biophy Res Commun 2008; 366: 545-550. http://dx.doi.org/10.1016/j. bbrc.2007.11.182

[15] OIKAWA D, KIMATA Y, KOHNO K, IWAWAKI T. Activation of mammalian IRE1alpha upon ER stress depends on dissociation of $\mathrm{BiP}$ rather than on direct interaction with unfolded proteins. Exp Cell Res 2009; 315: 2496-2504. http:// dx.doi.org/10.1016/j.yexcr.2009.06.009

[16] LEE AS. The glucose-regulated proteins: stress induction and clinical applications. Trends Biochem Sci 2001; 26: 504-510. http://dx.doi.org/10.1016/S0968-0004(01)01908-9

[17] DONG H, CHEN L, CHEN X, GU H, GAO G, et al. Dysregulation of unfolded protein response partially underlies proapoptotic activity of bortezomib in multiple myeloma cells. Leuk Lymphoma 2009; 50: 974-984. http://dx.doi. org/10.1080/10428190902895780

[18] LEE AS. GRP78 Induction in cancer: therapeutic and prognostic implications. Cancer Res 2007; 67: 3496-3499. http:// dx.doi.org/10.1158/0008-5472.CAN-07-0325

[19] RYU SH, CHUNG YH. How to overcome multidrug resistance in chemotherapy for advanced hepatocellular carcinoma. Liver Int 2010; 30:496-498. http://dx.doi.org/10.1111/j.1478-3231 $.2010 .02215 . \mathrm{x}$

[20] NI Z, BIKADI Z, ROSENBERG MF, MAO Q. Structure and function of the human breast cancer resistance protein(BCRP/ ABCG2).Cur Drug Metab 2010; 11: 603-617. http://dx.doi. org/10.2174/138920010792927325

[21] KORITA PV, WAKAI T, SHIRAI Y, MATSUDA Y, SAKATA J, et al. Multidrug resistance-associated protein 2 determines the efficacy of cisplatin in patients with hepatocellular carcinoma. Oncol Rep 2010; 23: 965-972.

[22] ZHOU G, KUO MT. NF- $\kappa$ B-mediated induction of mdr1b expression by insulin in rat hepatoma cells. J Biol Chem 1997; 272: 15174-15183. http://dx.doi.org/10.1074/ jbc.272.24.15174

[23] LEDOUX S, YANG R, FRIEDLANDER G, LAOUARI D. Glucose depletion enhances P-glycoprotein expression in hepatoma cells: Role of endoplasmic reticulum stress response. Cancer Res 2003; 63: 7284-7290.

[24] MORAND JP, MACRI J, ADELI K. Proteomic profiling of hepatic endoplasmic reticulum-associated Proteins in an animal model of insulin resistance and metabolic dyslipidemia. Biol Chem 2005; 280: 17626-17633. http://dx.doi.org/10.1074/jbc. M413343200

[25] MEI S, GU H, YANG X, GUO H, LIU Z, et al. Prolonged exposure to insulin induces mitochondrion-derived oxidative stress through increasing mitochondrial cholesterol content in hepatocytes. Endocrinology 2012; 153: 2120-2129. http:// dx.doi.org/10.1210/en.2011-2119

[26] LEE GH, KIM HK, CHAE SW, KIM DS, HA KC, et al. Bax inhibitor-1 regulates endoplasmic reticulum stress-associated reactive oxygen species and heme oxygenase- 1 expression. Biol Chem 2007; 282: 21618-21628. http://dx.doi.org/10.1074/jbc. M700053200

[27] LI J, LEE AS. Stress induction of GRP78/ BiP and its role in cancer. Curr Mol Med 2006; 6: 45-54. http://dx.doi. org/10.2174/156652406775574523

[28] WANG G, YANG ZQ, ZHANG K. Endoplasmic reticulum stress response in cancer: molecular mechanism and therapeutic potential. Am J Transl Res 2010; 2: 65-74.

[29] SMYTH MJ, KRASOVSKIS E, SUTTON VR. The drug efflux protein, P-glycoprotein, additionally protects drug-resistant tumor cells from multiple forms of caspase-dependent apoptosis. PNAS 1998; 95: 7024-7029. http://dx.doi.org/10.1073/ pnas.95.12.7024

[30] KOEHN J, FOUNTOULAKIS M, KRAPFENBAUER K. Multiple drug resistance associated with function of ABCtransporters in diabetes. mellitus: molecular mechanism and clinical relevance. Infect Disord Drug Targets 2008; 8: 109-118. http://dx.doi.org/10.2174/187152608784746510

[31] CUST ANNE E, STOCKS T, LUKANOVA A, LUNDIN E, HALLMANS G, et al. The influence of overweight and insulin resistance on breast cancer risk and tumour stage at diagnosis: a prospective study. Breast Cancer Res Treat 2009; 113: 567-576. http://dx.doi.org/10.1007/s10549-008-9958-8

[32] SIEGEL AB, ZHU AX. Metabolic syndrome and hepatocellular carcinoma: two growing epidemics with a potential link. Cancer 2009; 115: 5651-5661. http://dx.doi.org/10.1002/ cncr.24687

[33] ZHUANG L, SCOLYER RA, LEE CS. Expression of glucoseregulated stress protein GRP78 is related to progression of melanoma. Histopathology 2009; 54: 462-470. http://dx.doi. org/10.1111/j.1365-2559.2009.03242.x

[34] JIANG CC, MAO ZG, AVERY-KIEJDA KA, WADE M, HERSEY P, et al. Glucose-regulated protein 78 antagonizes cisplatin and adriamycin in human melanoma cells. Carcino- 
genesis 2009; 30: 197-204. http://dx.doi.org/10.1093/carcin/ bgn 220

[35] CHANDRIKA BB, MANEY SK, LEKSHMI SU, JOSEPH J, SEERVI M, et al. Bax deficiency mediated drug resistance can be reversed by endoplasmic reticulum stress induced death signaling. Biochem Pharmacol 2010; 79: 1589-1599. http:// dx.doi.org/10.1016/j.bcp.2010.01.032

[36] LEE E, NICHOLS P, SPICER D. GRP78 as a novel predictor of responsiveness to chemotherapy in breast cancer. Cancer Res 2006, 66: 7849-7853. http://dx.doi.org/10.1158/0008-5472. CAN-06-1660

[37] MA K, VATTEM KM, WEK RC. Dimerization and release of molecular chaperone inhibition facilitate activation of eukaryotic initiation factor-2 kinase in response to endoplasmic reticulum stress. Biol Chem 2002; 277: 18728-18735. http:// dx.doi.org/10.1074/jbc.M200903200

[38] CHEN J, WEI H, XIE B, WANG B, CHENG J, et al. Endoplasmic reticulum stress contributes to arsenic trioxide-induced apoptosis in drug-sensitive and -resistant leukemia cells. Leuk Res 2012; 36: 1526-1535. http://dx.doi.org/10.1016/j. leukres.2012.08.018

[39] NAKATANI Y, KANETO H, KAWAMORI D, HATAZAKI M, MIYATSUKA T, et al. Modulation of the JNK pathway in liver affects insulin resistance status. J Biol Chem 2004; 279: 45803-45809. http://dx.doi.org/10.1074/jbc.M406963200

[40] SHCHORS K, EVAN G. Tumor angiogenesis: cause or consequence of cancer? Cancer Res 2007; 67: 7059-7061. http:// dx.doi.org/10.1158/0008-5472.CAN-07-2053

[41] YE R, JUNG DY, JUN JY, LI J, LUO S, et al. Grp78 heterozygosity promotes adaptive unfolded protein response and attenuates diet-induced obesity and insulin resistance. Diabetes 2010; 59: 6-16. http://dx.doi.org/10.2337/db09-0755

[42] VAN DER KALLEN CJ, VAN GREEVENBROEK MM, STEHOUWER CD, SCHALKWIJK CG. Endoplasmic reticulum stress-induced apoptosis in the development of diabetes: is there a role for adipose tissue and liver? Apoptosis 2009; 14: 1424-1434. http://dx.doi.org/10.1007/s10495-009-0400-4

[43] ZHOU SF. Structure, function and regulation of P-glycoprotein and its clinical relevance in drug disposition. Xenobiotica 2008; 38: 802-832. http://dx.doi.org/10.1080/00498250701867889

[44] SMYTH MJ, KRASOVSKIS E, SUTTON VR. The drug efflux protein, P-glycoprotein, additionally protects drug-resistant tumor cells from multiple forms of caspase-dependent apoptosis. PNAS 1998; 95: 7024-7029. http://dx.doi.org/10.1073/ pnas.95.12.7024

[45] TESTA U, RICCIONI R. Deregulation of apoptosis in acute myeloid leukemia. Haematologica 2007; 92: 81-94. http:// dx.doi.org/10.3324/haematol.10279

[46] BANSAL T, JAGGI M, KHAR RK, TALEGAONKAR S. Emerging significance of flavonoids as P-glycoprotein inhibitors in cancer chemotherapy. J Pharm Pharm Sci 2009; 12: 46-78.

[47] MUNTEANU E, VERDIER M, GRANDJEAN-FORESTIER F, STENGER C, JAYAT-VIGNOLES C, et al. Mitochondrial localization and activity of P-glycoprotein in doxorubicinresistant K562 cells. Biochem Pharmacol 2006; 71: 1162-1174. http://dx.doi.org/10.1016/j.bcp.2006.01.006

[48] THOMAS J, WANG L, CLARK RE, PIRMOHAMED M. Active transport of imatinib into and out of cells: implications for drug resistance. Blood 2004; 104: 3739-3745. http://dx.doi. org/10.1182/blood-2003-12-4276

[49] LEDOUX S, YANG R, FRIEDLANDER G, LAOUARI D. Glucose depletion enhances p-glycoprotein expression in hepatoma cells role of endoplasmic reticulum stress response. Cancer Res 2003; 63: 7284-7290.

[50] HO MM, HOGGE DE, LING V. MDR1 and BCRP1 expression in leukemic progenitors correlates with chemotherapy response in acute myeloid leukemia. Exp Hem atol 2008; 36: 433-442. http://dx.doi.org/10.1016/j.exphem.2007.11.014

[51] CHO N, MOMOSE Y. Peroxisome proliferators 2 activated receptor gamma agonists as insulin sensitizers: from the discovery to recent progress. Curr Top Med Chem 2008; 8: 1483-1507. http://dx.doi.org/10.2174/156802608786413474

[52] J L COUSIN, M SAMSON, P F PILCH, M FEHLMANN. Internalization of insulin receptors and HLA antigens in human hepatoma cells. Biochem J 1987; 242: 403-410

[53] B MELIN, G CHERQUI, M J BLIVET, M CARON, O LASCOLS, et al. Dual effect of metformin in cultured rat hepatocytes: potentiation of insulin action and prevention insulin-induced resistance. Metabolism 1990; 39:1089-1095 http://dx.doi.org/10.1016/0026-0495(90)90171-8

[54] HSIAO YP, LIN HS, WU TW. A comparative study of KOH test, PAS staining and fungal culture in diagnosis of onychomycosis in Taiwan. Dermatological Science 2007; 45:138-140 http:// dx.doi.org/10.1016/j.jdermsci.2006.09.006 